\title{
Dynamics of Changes in the Concentration of Oil Products in the Tura River within the Residential Area of the Large Oil Capital of Russia
}

\author{
Alexander V. Kryakhtunov ${ }^{1 *}$ \\ 1 Federal State Budget Educational Institution of Higher Education, Industrial University of Tyumen, \\ Volodarskogo Street 38, 652001 Tyumen, Russia \\ * Corresponding author's e-mail: krjahtunovav@tyuiu.ru
}

\begin{abstract}
In the course of the study, the following tasks were solved: determining the level of oil products and their spatial distribution in surface waters and bottom sediments of the Tura River, studying the features of the accumulation of oil products in bottom sediments in different sections of the Tura River, as well as the effect of storm and melt water contaminated with oil products within the coastal boundaries on the general background of pollution, calculated by the approximation method the distance at which the maximum permissible concentration for the Tura River would be reached, gave recommendations on the preservation of the object under study. The research was carried out in the laboratory of the Tyumen Industrial University. The analysis of samples for the content of oil products was carried out by the fluorometric method on a fluid analyzer "Fluorat-02-2M". The results of the study indicate the need to monitor surface waters and toughly respond to insufficient compliance with the standards for the protection of surface waters and bottom sediments within the city of Tyumen.
\end{abstract}

Keywords: hydrosphere, surface water, bottom sediments, oil products, oil pollution, runoff

\section{INTRODUCTION}

One of the main and important problems of the modern world, which must be resolved in a radical way, is the widespread pollution of water bodies and watercourses on Earth as a result of anthropogenic influences.

This is especially important for those water bodies that cities use for the intake of water for household and drinking needs, as well as for the provision of technological processes of enterprises. Each region of Russia is faced not only with an ecological, but also with a social problem, such as the state of intracity water bodies.

The class of anthropogenic sources that have a negative impact on the quality of natural waters and bottom sediments includes various plants and factories, enterprises of the chemical, metallurgical, woodworking, food and processing industries, river and water transport, municipal waste dumps in urban areas located near the reservoir as well as roads and railways passing over or along water bodies. Some anthropogenic sources discharge their untreated sewage, contaminated with oil products, garbage and various kinds of waste into the water area of the Tura River and other water bodies of the city of Tyumen. Also, unorganized runoff from the adjacent territories of residential areas of the city and already polluted groundwater also adversely affects the hydrological, hydrobiological and hydrochemical regime of the river in the city of Tyumen.

Oil pollution of a water body leads not only to a decrease in the content of dissolved oxygen in the water, as a result of which the process of selfpurification of a water body slows down, but also leads to the death of waterfowl, fish, a reduction in the species of flora and fauna, and undoubtedly has a detrimental effect on the urban population (Fordyce 2013). In this connection, the assessment of the current state of water bodies in the city of Tyumen is of current importance. In 
particular, the Tura river is strategically important for the city, because it is one of the sources of water supply for the population, which makes the assessment of surface water and bottom sediments more significant.

The aim of the work is to study the features of the distribution and accumulation of oil products in the "water - bottom sediments" system to determine the level of technogenic pollution in the Tura River within the residential area of the city of Tyumen.

\section{MATERIAL AND METHODS}

Tura is a large river, the left tributary of the Tobol River, its length is $1030 \mathrm{~km}$. The main part of the river flows in the Sverdlovsk region, in the Kushvinsky, Nizhneturinsky, Verkhotursky, Alapaevsky, Turinsky and Slobodo-Turinsky districts. The direction of the river is east. Settlements on the shore: Vologina, Kosolmanka, Privokzalny, Verkhoturye, Krasnogorskoe, Ust Salda, Kordyukovo, Bolotovskoe, Sonkino, Zhukovskoe, Shukhrupovskoe, Turinsk, Pushkarevo, Sladkovskoe, Turinskaya Sloboda, Ust-Nitsinskoe, Kamenka, Kulakovo, Chulakovo.

At the top of the catchment area, massivecrystalline effusive and intrusive rocks predominate; in the middle of the path, sandy-loamy soils with a small amount of sandy loam predominate. In the lower part of the catchment area, mostly sedimentary sandy loam rocks prevail. The soil is podzolic, sometimes there are wetlands. Closer to the southern wing, sod-podzolic and gray forest soils prevail. Not far from the city of Nizhnyaya

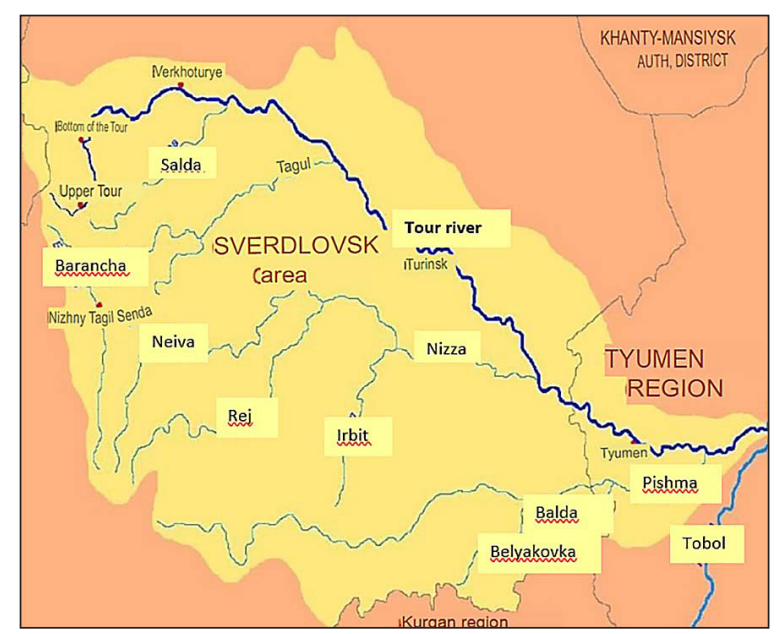

Fig. 1. Territorial diagram of the location of the investigated object, the river Tour
Tura, in the upper reaches of the basin of the Neiva and Tagil rivers, there are karst phenomena.

The swampiness of the Tura River is increasing from the western part to the eastern and is about $20 \%$. The lakes are located mainly in the mountainous part of the river, and in the interfluve.

One of the features of the river's hydrochemical regime is the increased content, the increased content of organic matter and iron, as well as manganese, zinc and copper. The water in the Tura River is steadily polluted. Water quality in the sections of the city Tyumen corresponds to the class "extremely dirty". Mainly the Tura river is polluted with phenols, oil products, nitrogen compounds, heavy metals.

\section{RESULTS}

The object of the study is the Tura river within the urban area. The length of the study area is $12 \mathrm{~km}$. To conduct a study and study the dynamics of the accumulation of oil products in bottom sediments and surface waters of a water body within the residential area, samples were taken in September from 2017 to 2020. Each year, 12 water and bottom sediment samples were taken along the Tura river bank.

And also for a more complete picture of the pollution of the water body, we took 12 samples of snow cover at the same points as the samples of water and bottom sediments. Snow sampling was carried out in late February - early March 2020, 2021 (Wang et al., 2018). Sampling of snow cover was carried out in accordance with GOST 17.1.5.05-85. "Protection of Nature. Hydrosphere. General requirements for sampling of surface and sea waters, ice and

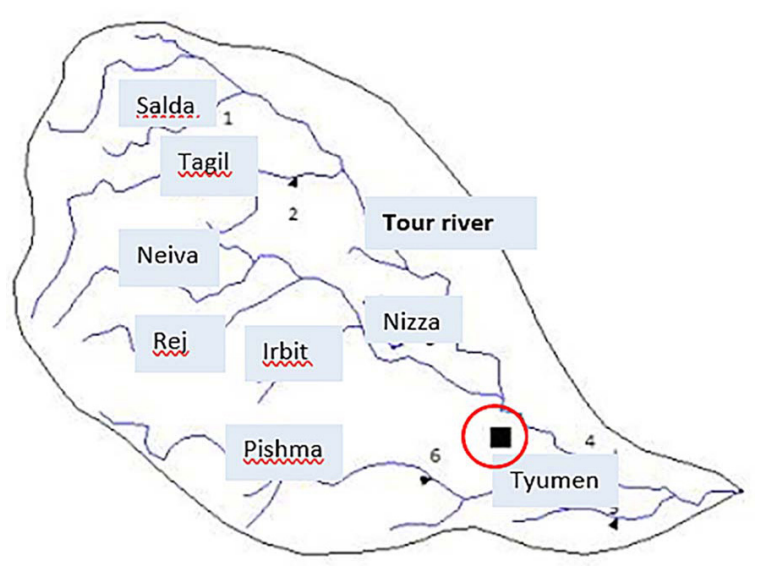

Fig. 2. Location of observation posts on the Tour river 
atmospheric precipitation". The sampling sites for bottom sediments, water and snow cover are shown in Figure 3.

The research was carried out in the laboratory of the Tyumen Industrial University. The studies were carried out as follows: Filtered water samples with a volume of $100 \mathrm{ml}$ were introduced into a separating funnel with a capacity of $250 \mathrm{~cm}^{3}$. Using a pipette, we took $10 \mathrm{~cm}^{3}$ of hexane, rinse the vessel containing the sample with it and place this hexane in a separatory funnel. We extract the sample by shaking it vigorously for 3 minutes. Next, let the solution settle until the interface appears on the surface. We separate the detached layer from the remaining sample and transfer it to the cuvette, having previously rinsed it with a hexane solution. Then we transfer the cuvette to the Fluorat-02-2m liquid analyzer and carry out the measurement. We collect the water phase in a graduated cylinder and accurately record its volume.

As a comparison of water quality, we used the maximum permissible concentration for water bodies of public utility value and the maximum permissible concentration for water bodies of fishery significance. To represent the dynamics of pollution, we used the results of the study of samples of surface and bottom sediments of the Tura River, carried out in 2011 at the Tyumen State University of Architecture and Civil Engineering. The results of analyzes on the content of oil products in the surface waters of the Tura River for 2017-2020 are presented in Figures 4-8 (Chemagin, 2020).

As a result of the analysis of the data obtained during the study of the content of oil products in surface waters, we observe a significant excess of MPC.b $\left(0.3 \mathrm{mg} / \mathrm{dm}^{3}\right)$. The maximum concentration of surface water pollution by oil products exceeds the MPC by more than 300 times (Gordeev et al. 2014). The highest concentration of pollution is observed at points $4,6,8$ and 11 . It should be noted that in comparison with the samples of 2011, over 7 years, the amount of oil products in the surface waters of the Tura River has increased several times, 3-8 times, and at point 2 - in 50 times due to the turn of the river bed (Chemagin, 2020)

At the points where the maximum concentration of surface water pollution is observed, various anthropogenic sources were a possible factor causing such pollution. Research of oil products in bottom sediments is necessary, since they are considered as an indicator and objects of monitoring the ecological state for a long period of time. Samples were taken at the same time as surface waters.

The results of studies on the content of oil products in the bottom sediments of the Tura River (Figure 9) showed similar results with the content of oil products in surface waters. In bottom sediments, the values varied from 6.67 to $\mathrm{mg} / \mathrm{kg}$ to $421.6 \mathrm{mg} \mathrm{kg}$. We also observe that the content of oil products in bottom sediments is quite high, which may indicate the accumulation of oil products by bottom sediments.

Studies of the effect of snow cover (melt water) on the dynamics of the growth of oil products in water and bottom sediments in the Tura River have shown that oil-contaminated snow cover during the snowmelt period can increase the concentration of oil products in water and further in bottom sediments, thereby making its negative contribution to the total Tura river pollution background (Chemagin, 2020).

Investigations of surface waters and bottom sediments for the content of oil products of the Tura River have shown a stable dynamics of the growth of pollution with these substances. At the same time, the content of oil products in bottom sediments exceeds their concentration in water, which indicates the accumulation of this pollutant by them (Soliman et al. 2018).

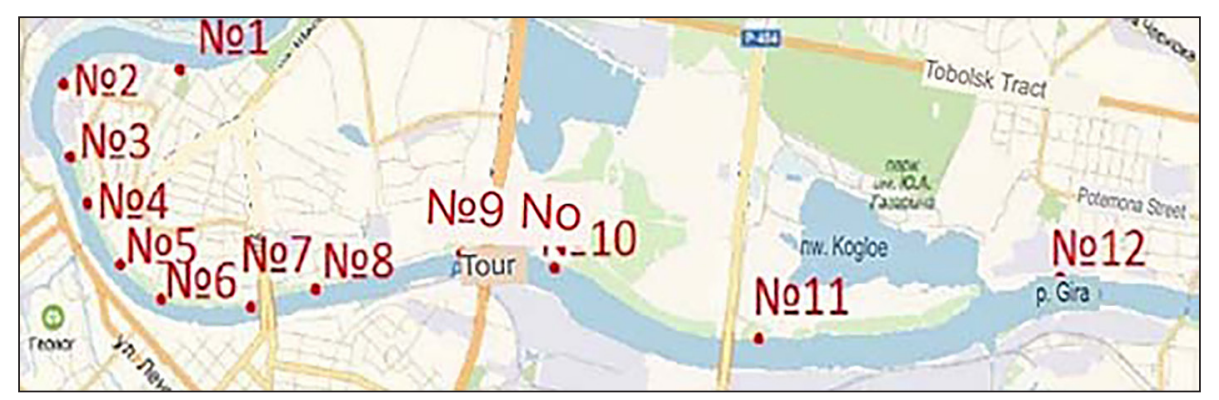

Fig. 3. Sampling points of water, bottom sediments and snow cover of the investigated object of the Tour river 
$\square 2017$

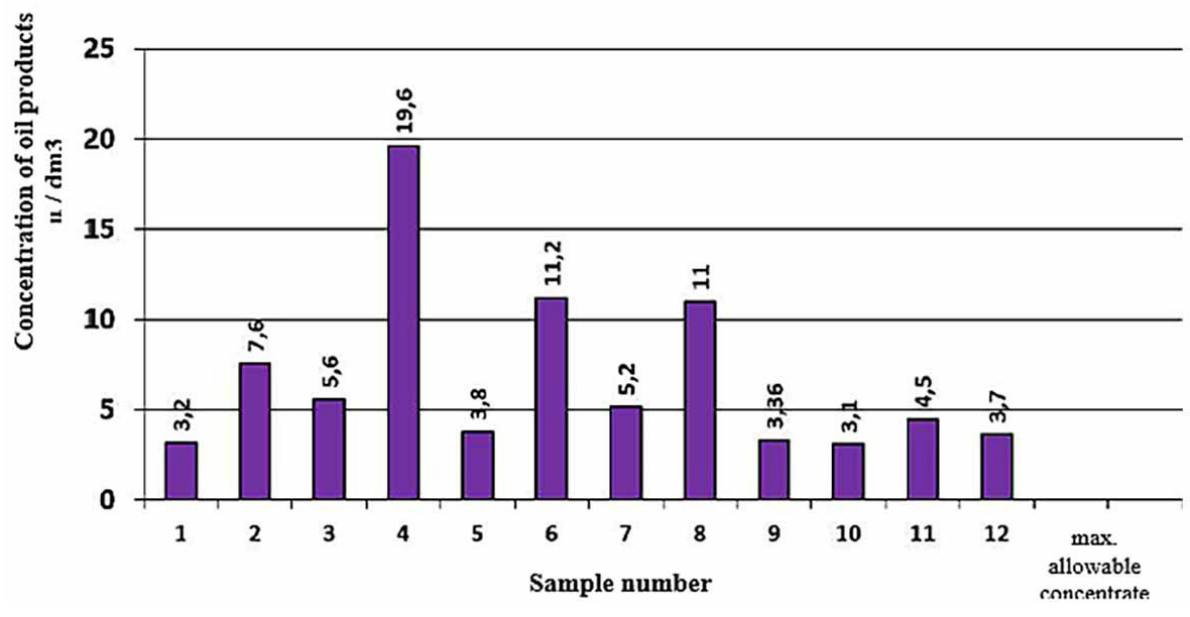

Fig. 4. Content of oil products in the surface waters of the Tura River for 2017

\section{$\square 2018$}

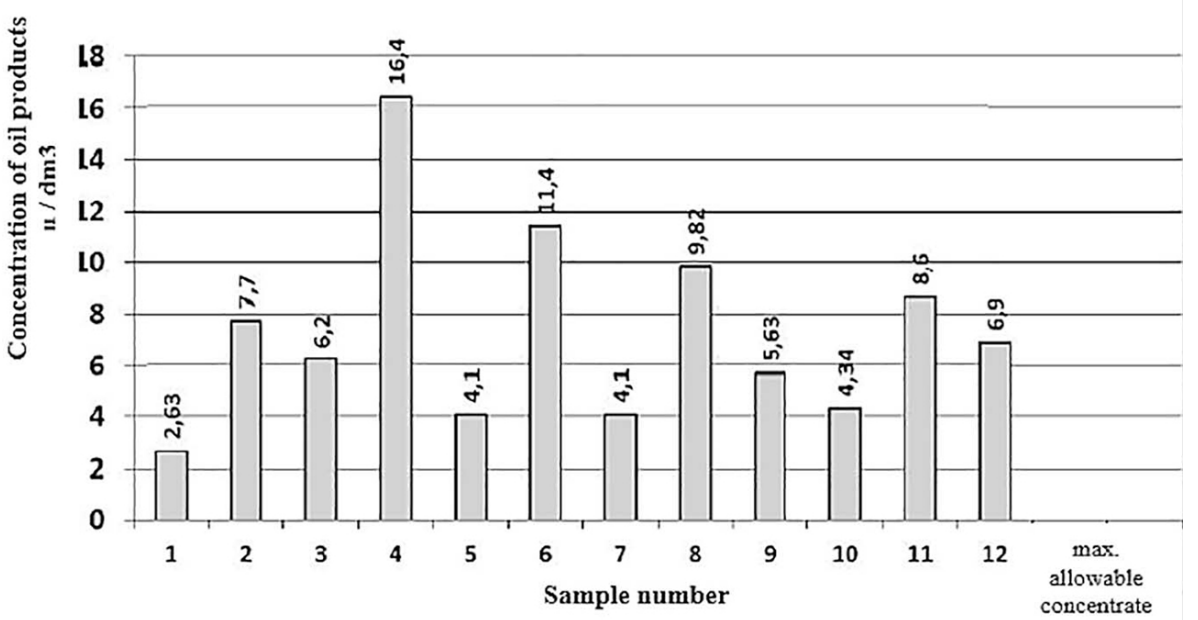

Fig. 5. Content of oil products in the surface waters of the Tura River for 2018

$\square 2019$

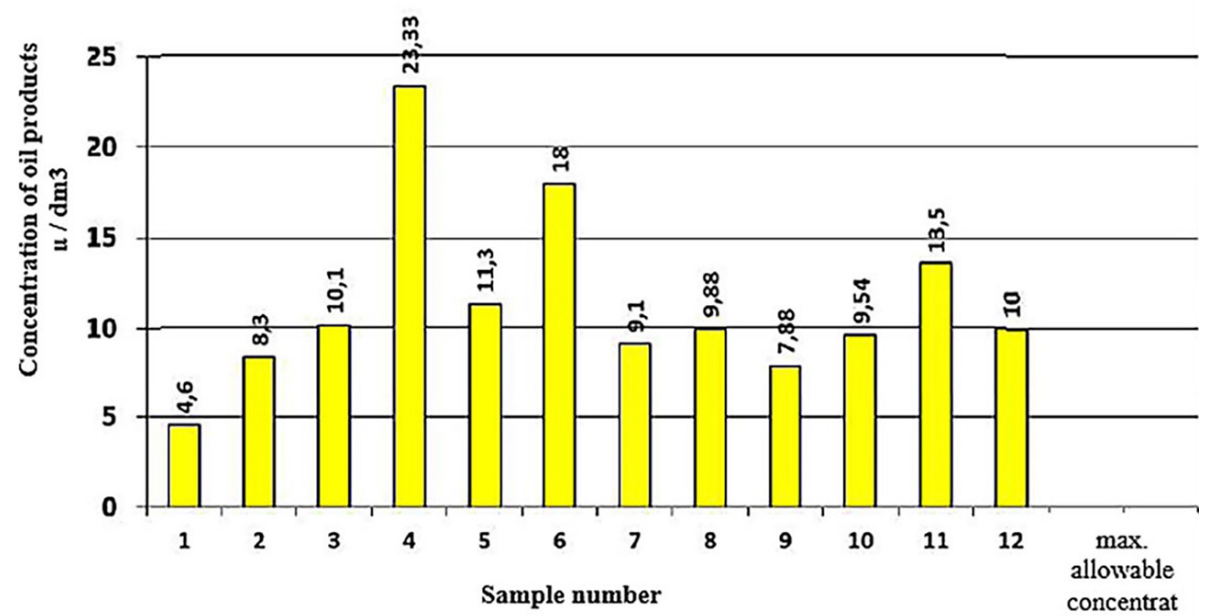

Fig. 6. Content of oil products in the surface waters of the Tura River in 2019 


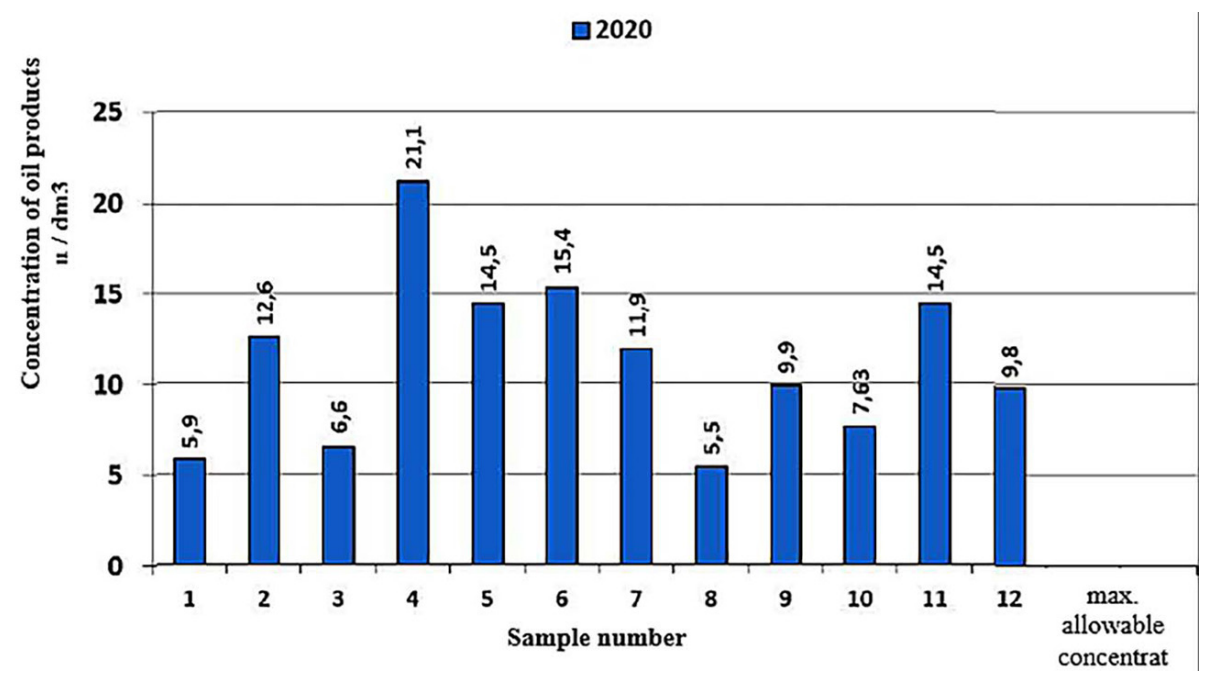

Fig. 7. Content of oil products in the surface waters of the Tura River for 2020

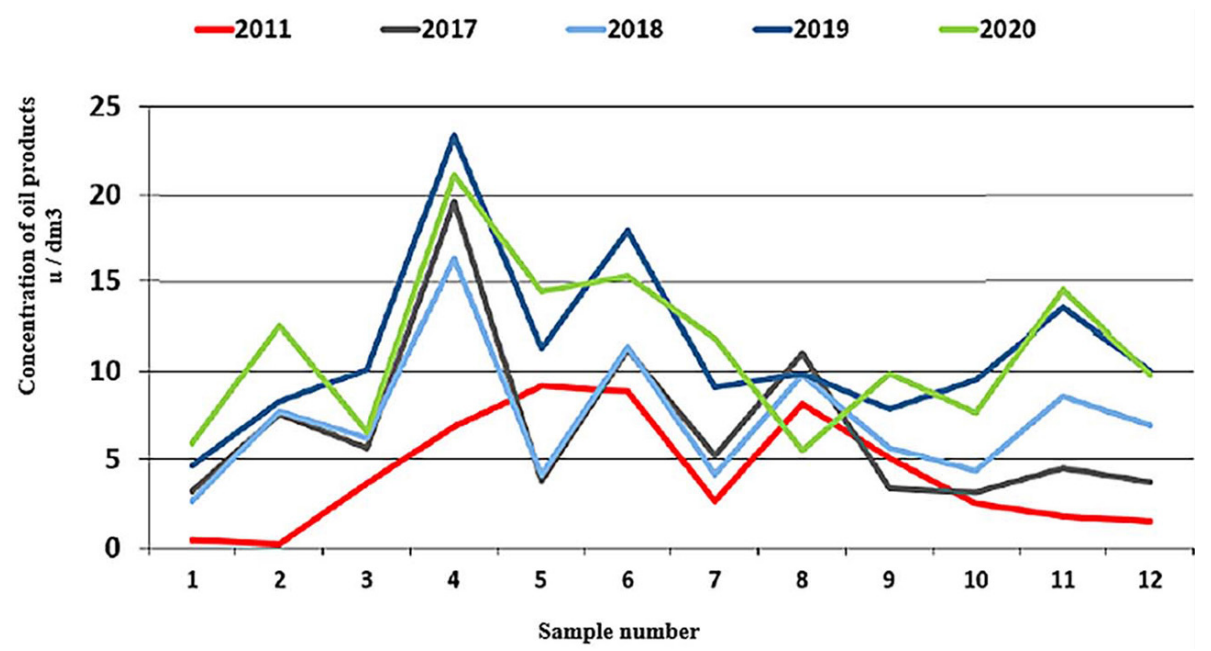

Fig. 8. Comparative content of oil products in the surface waters of the Tura River for 2011 and 2017-2020

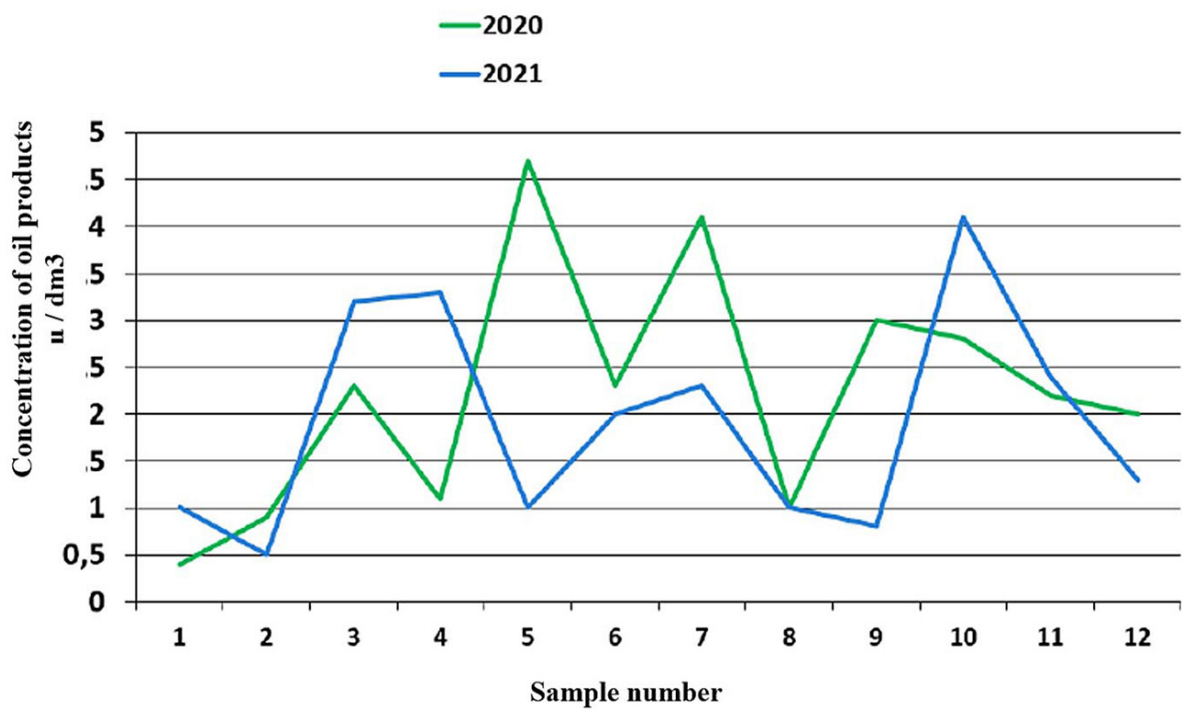

Fig. 9. Comparison of the content of oil products in the bottom sediments of the Tura River for 2011 and 2017-2020 


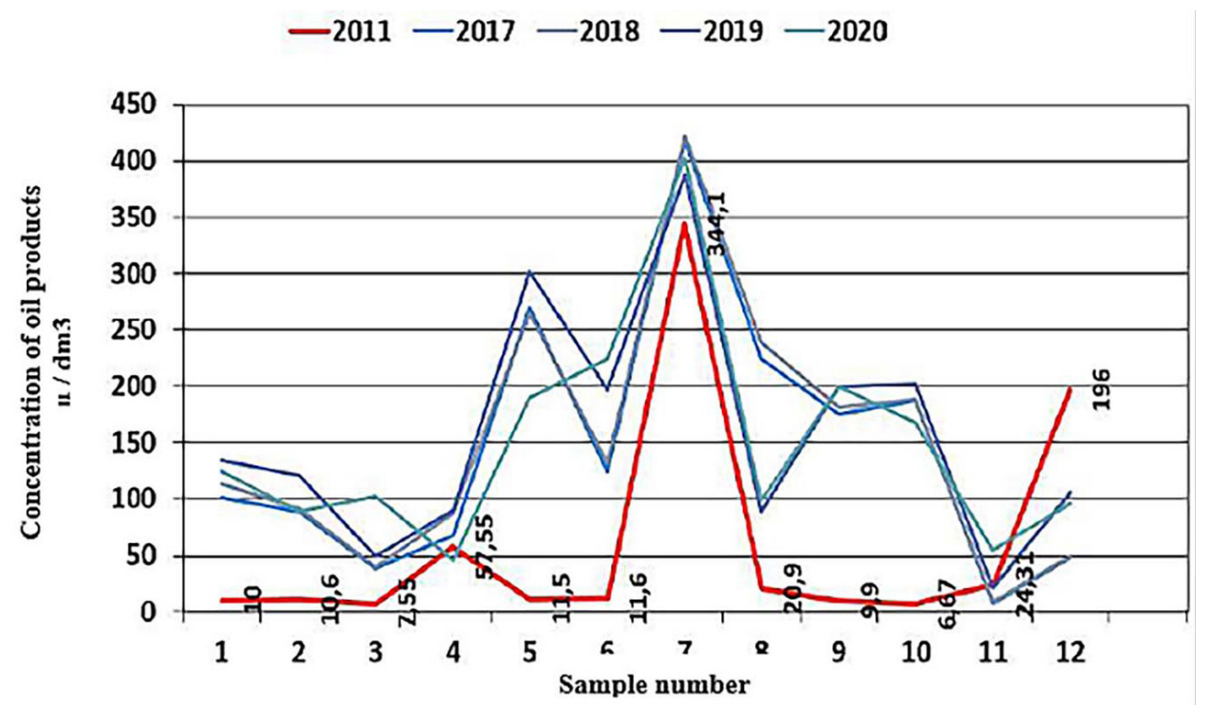

Fig. 10. The content of oil products in the melt waters of the snow cover on the Tura River for 2020-2021

\section{CONCLUSIONS}

Investigations of surface waters for the content of oil products of the Tura River showed a stable dynamics of the growth of pollution with these substances. At the same time, the content of oil products in surface waters indicates a longterm accumulation of this pollutant. It should be noted that the waters of the Tura River are transboundary. Thus, after analyzing the data obtained on the surface waters of the Tura River for a nineyear period, it can be concluded that the intensity of pollution of this reservoir is increasing and, compared with the data of previous years, the concentration of oil production has higher values. As a result, some parts of the river can be classified as "hazardous".

In this regard, our side offers the following recommendations:

- To conduct annual environmental monitoring of the state of surface waters and bottom sediments of the Tura River within the city of Tyumen.

- It is necessary to respond to non-compliance with the norms for the protection of surface waters and bottom sediments within the city of Tyumen.

- It is necessary to inform the population by installing information boards about the reaction to non-observance of the norms for the protection of surface waters and bottom sediments within the city of Tyumen.

- to abandon the intake of water for household and drinking needs and switch to the intake of water from underground sources.
- Reducing the anthropogenic load on the water body by reducing the use of recreational activities in the reservoir and in the immediate vicinity of the coastline.

\section{REFERENCES}

1. Fordyce F.M. 2013. Selenium deficiency and toxicity in the environment. In: Selinus O. (ed.), Essentials of Medical Geology: Rev Edn. British Geological Survey, 375-419.

2. Gordeev V.V., Lisitzin A.P. 2014. Geochemical interaction between the freshwater and marine hydrospheres. Russian Geology and Geophysics, 55(5-6), 562-581. (in Russian)

3. Khayrulina E.A., Ushakova E.S. 2020. Particularities of the development of the macro component composition of the snow cover in a large center of the potash industry, the city of Berezniki. Regional Environmental Issues, 3, 28-38. (in Russian)

4. La Frenierre J., Mark B.G. 2014. A review of methods for estimating the contribution of glacial meltwater to total watershed discharge. Prog. Phys. Geogr., 38, 173-200.

5. Lebedev S.V., Agafonova E.K. 2017. Ecogeochemical estimation of environmental pollution by monitoring data of heavy metals contamination in soil and snow cover (at the example of Vasileostrovsky district of Saint Petersburg). Vestnik SPbSU. Earth Sciences, 62(4), 357-369. DOI: 10.21638/11701/ spbu07.2017.403 (in Russian).

6. Ryazantseva A.V. 2019.Monitoring of naturalterritorial complex in the zone of oil and gas development (on materials of Bovanenkovo NGKM, Yamal district, YNAO). Collection of theses of VII 
regional youth conference named after Shpilman V.I. Problems of rational nature management and history of geological prospecting in Western Siberia, Khanty-Mansiysk, March 28-29, 2019. Khanty-Mansiysk. Yugorsky Format. Limited Liability Company, 135-138.

7. Soliman M., Eldyasti A. 2018. Ammonia-Oxidizing Bacteria (AOB): opportunities and applications-a review. Reviews in Environmental Science and Bio/ Technology, 17, 285-321. DOI: $10.1007 /$ s11157018-9463-4 14.
8. Wang L., Zhang J., Li H., Yang H., Peng C., Peng Z., Lu L. 2018. Shift in the microbial community composition of surface water and sediment along an urban river. Science of The Total Environment, 627, 600-612. DOI: 10.1016/j.scitotenv.2018.01.203

9. Wang N., Gao J., Liu Y., Wang Q., Zhuang X., Zhuang G. 2021. Realizing the role of N-acylhomoserine lactone-mediated quorum sensing in nitrification and denitrification: A review. Chemosphere, 274, 129970. DOI: 10.1016/j. chemosphere.2021.129970 